\title{
Perkinsus marinus tissue distribution and seasonal variation in oysters Crassostrea virginica from Florida, Virginia and New York
}

\author{
L. M. Oliver ${ }^{1, *}$, W. S. Fisher ${ }^{1}$, S. E. Ford ${ }^{2}$, L. M. Ragone Calvo ${ }^{3}$, E. M. Burreson ${ }^{3}$, \\ E. B. Sutton ${ }^{4}$, J. Gandy ${ }^{2}$
}

${ }^{1}$ U.S. EPA National Health and Environmental Effects Research Laboratory, Gulf Ecology Division, 1 Sabine Island Drive, Gulf Breeze, Florida 32561-5299, USA

${ }^{2}$ Haskin Shellifish Research Laboratory, Institute of Coastal and Marine Sciences, 6959 Miller Avenue, Port Norris, New Jersey 08349-9736, USA

${ }^{3}$ Virginia Institute of Marine Science, Gloucester Point, Virginia 23062, USA

${ }^{4}$ PO Box 101669, Gainesville, Florida 32610, USA

\begin{abstract}
Perkinsus marinus infection intensity was measured in eastern oysters Crassostrea virginica collected in October and December 1993, and March, May, and July 1994 from 3 U.S. sites: Apalachicola Bay (FL), Chesapeake Bay (VA), and Oyster Bay (NY). Gill, mantle, digestive gland, adductor muscle, hemolymph, and remaining tissue (including gonadal material and rectum) were dissected from 20 oysters from each site at each collection time. Samples were separately diagnosed for $P$. marinus infections by incubation in Ray's Fluid Thioglycollate Medium (RFTM) and subsequent microscopic quantification of purified enlarged hypnospores. At all sampling times and sites, average $P$. marinus infection intensity ( $\mathrm{g}$ wet wt tissue $\mathrm{e}^{-1}$ or $\mathrm{ml} \mathrm{hemolymph}^{-1}$ ) was lowest in hemolymph samples, and generally highest in the digestive gland. Perkinsus marinus prevalence was $100 \%$ at both FL and NY sites for each of the 5 collection times, and, for the VA site, was less than $100 \%$ in only 1 month (May 1994). Seasonal intensity patterns and mean total body burdens differed among the sites. Average body burden was highest in VA during October and progressively declined to a minimum in May. This decline was probably due to mortality of heavily infected oysters and diminution of parasite activity associated with colder temperatures and reduced salinities. Intensities varied little during the months of October and December at both the FL and NY sites. Minimum average intensities were observed in March in FL oysters and May in NY oysters. Relatively high P. marinus infection levels that persisted throughout the winter in NY oysters compared with VA oysters could reflect constant high salinity in Long Island Sound which favors parasite activity, and also rapid decline in temperature in the fall that may have prevented epizootic oyster mortalities.
\end{abstract}

KEY WORDS: Perkinsus marinus - Crassostrea virginica - Tissue distribution - Body burdens - Seasonal variation - Geographic variation

\section{INTRODUCTION}

The parasite Perkinsus marinus, previously classified as Dermocystidium marinum, is responsible for widespread mortalities in oysters Crassostrea virginica from the Gulf of Mexico to Delaware Bay (Mackin 1953, Andrews 1988, Andrews 1996, Burreson \& Ragone

•E-mail: oliver.leah@epamail.epa.gov
Calvo 1996, Soniat 1996). Recent documentation of $P$. marinus in Long Island Sound (Brousseau et al. 1994) and Maine (Kleinschuster \& Parent 1995) indicates extension of its range to include most of the U.S. Atlantic coast and the Gulf of Mexico south to Laguna Madre in Texas (Craig et al. 1989), the Florida Keys (Quick \& Mackin 1971), and Mexico (Burreson et al. 1994). Oyster mortalities from P. marinus usually peak in late summer-autumn when combined high tempera- 
ture and high salinity conditions in many oyster habitats favor development of heavy infections (Ray 1954 , Andrews 1955, Andrews 1988). Diminished infection intensity and prevalence occur during winter months, and then infections intensify in spring and summer as temperatures rise (Beckert et al, 1972, Ogle \& Flurry 1980, Crosby \& Roberts 1990, Bushek et al. 1994. Ragone Calvo \& Burreson 1994).

The tendency for low temperature and low salinity to limit the severity of Perkinsus marinus infections was recognized by Mackin et al. (1950). In moderate to high salinities, temperatures $\geq 25^{\circ} \mathrm{C}$ are usually associated with heavy $P$. marinus infection intensities while temperatures $<10^{\circ} \mathrm{C}$ limit growth of the pathogen (Andrews \& Hewatt 1957, Andrews 1965, Perkins 1966). P. marinus requires salinities of at least $12 \%$ for infections to intensify, and increasing salinity has been positively associated with infection intensity in laboratory and field studies (Andrews 1988, Chu et al. 1993, Ragone \& Burreson 1993).

Despite the strong influence of season and salinity on pathogenicity of Perkinsus marinus, these factors do not entirely explain the variability in infection intensity and oyster mortalities. For example, $P$. marinus prevalence and intensity in South Carolina oysters from a relatively low salinity intertidal site were higher than those of oysters from an oceanic site (Burrell et al. 1984). Weighted incidences (WI) of oysters from west Galveston Bay (Texas) measured from May 1979 to September 1981 showed no obvious seasonal pattern, but showed a strong correlation with temperaturesalinity interaction $(\mathrm{T} \times \mathrm{S}$ ) (Soniat 1985). P. marinus infection intensity and related oyster mortalities can also be exacerbated by poor nutritional status (Fisher et al. 1992), by high oyster density (Andrews 1996), and by exposure to certain xenobiotic chemicals (Scott et al. 1985, Winstead \& Couch 1988, Chu \& Hale 1994, Anderson et al. 1996, Fisher et al. 1995). P. marinus infection progression and pathogenicity are influenced by numerous fluctuating abiotic and biotic factors.

Ray's (1952) original technique to diagnose Perkinsus marinus infection severity in oysters involves dissection of a select tissue such as rectum or mantle, incubation of the tissue in Ray's Fluid Thioglycollate Medium (RFTM) to enlarge parasites, staining with iodine, and microscopic examination to enumerate parasites. Mackin (1951) and Ray (1952) recognized that variation in parasite density (no. of parasites $\mathrm{g}^{-1}$ ) within and among different oyster tissues could bias diagnostic methods. New diagnostic methods to quantify $P$. marinus confirmed that parasite distribution varies among oyster tissues. Lewis et al. (1988) first developed a method to quantify parasites, and others (Choi et al. 1989, Fisher et al. 1992) demonstrated that digestive gland tissue had higher parasite densities than other tissues. Gauthier \& Fisher (1990) first used the quantitative method to determine the entire oyster's parasite burden, and showed that hemolymph $P$. marinus levels $\left(\mathrm{ml}^{-1}\right)$ were lower than the total body burdens $\left(\mathrm{g}^{-1}\right)$. The quantitative total body burden assay is more sensitive than the tissue squash technique (Bushek et al. 1994). However, comprehensive analysis of parasite compartmentalization in all oyster tissues has not yet been performed.

The objectives of this study were to concurrently monitor Perkinsus marinus infection patterns in 3 geographically distinct oyster populations, to compare and contrast differences in disease prevalence and intensity at those sites over a 1 yr period, and to study tissue distribution of the parasite by performing quantitative diagnoses on separate oyster tissues. Since individual tissues are often examined to estimate body burden, this approach allowed comparison of the accuracy of using various tissues to indicate total body levels of $P$. marinus. The 3 laboratories participating in the collaborative study employed a standard technique to enumerate parasites in 6 tissues, and calculated total oyster burden by summation.

\section{MATERIALS AND METHODS}

Oyster collection. At each collection time (October and December 1993, March, May, and July 1994), approximately 25 oysters were gathered from 3 sites (see below) using hand tongs in FL and a dredge in VA and NY, placed on ice and transported to the Environmental Protection Agency's Gulf Ecology Division (GED, FL oysters), Virginia Institute of Marine Science (VIMS, VA oysters), or Haskin Shellfish Research Laboratory (HSRL, NY oysters). Florida (FL) oysters were collected from Cat Point Bar in Apalachicola Bay (Northern Gulf Coast of Florida, Fig. 1a), an actively fished oyster bar that experiences diurnal tides and frequent salinity fluctuations. Cat Point Bar salinity typically ranges from 0 to $30 \%$. Annual temperatures range from 8 to $33^{\circ} \mathrm{C}$. Virginia (VA) oysters were collected from Wreck Shoal in the upper James River, an oyster seed bed in a low to moderate salinity area (lower Chesapeake Bay, Fig. 1b). Wreck Shoal has a mean annual salinity of about $14 \%$ with minimum salinities typically in March resulting from high runoff, and maximums in October Annual temperatures usually range from 2 to $28^{\circ} \mathrm{C}$. New York (NY) oysters originated from the planting grounds of the Frank $M$. Flower \& Sons Oyster Company' in Oyster Bay fLong Island Sound, Fig. 1c). Oyster Bay is well mixed with

\footnotetext{
'Mention of commercial names does not constitute endorsement by the U.S. Environmental Protection Agency
} 
Fig. 1 Locations of oyster sampling sites ( $\star$ ) at (a) Cat Point Bar, Apalachicola Bay, Florida; (b) Wreck Shoal, James River. Chesapeake Bay, Virginia; (c) Oyster Bay, Long Island Sound, New York

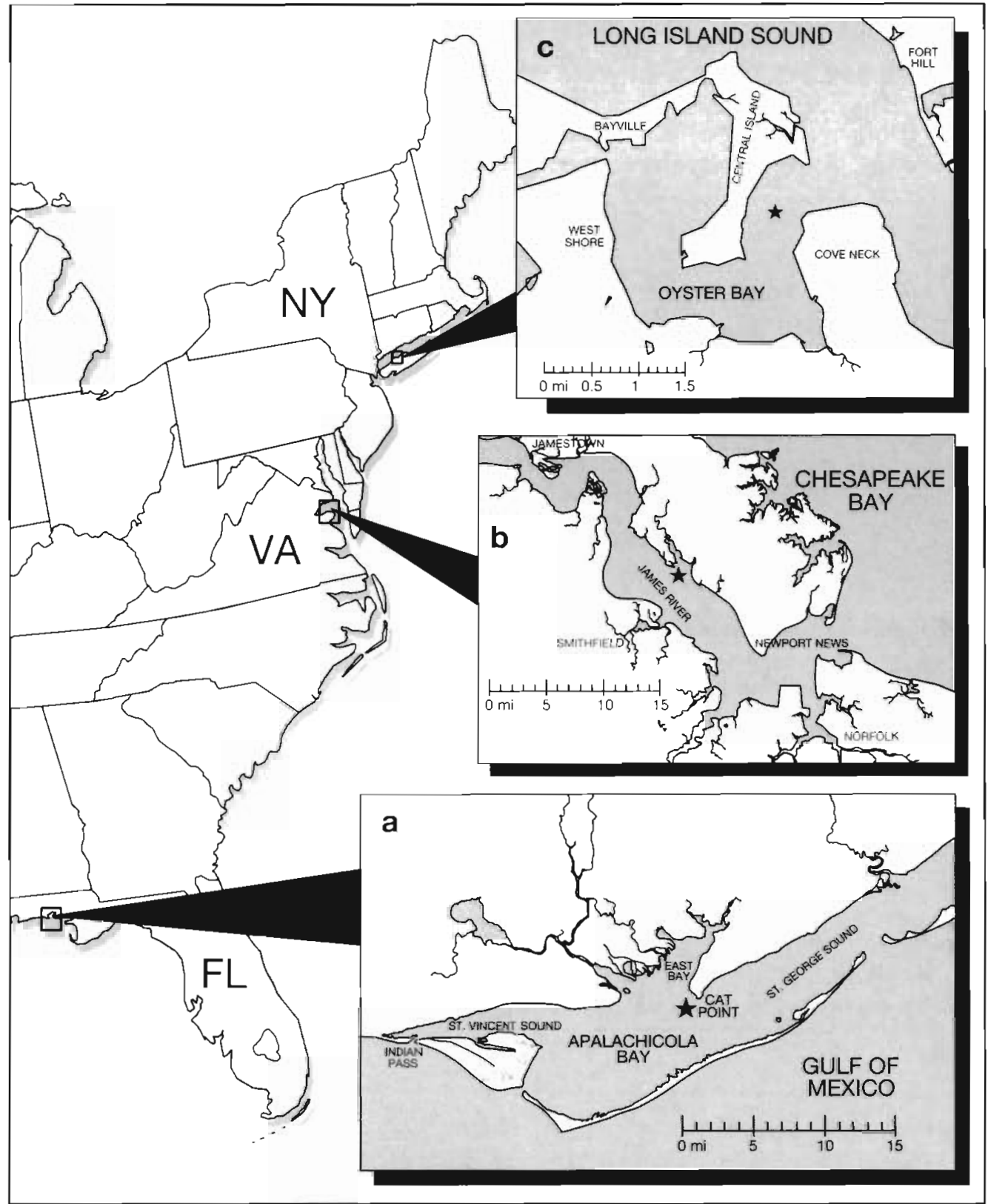

oysters were shucked, and shells and meat were weighed separately. The following tissues were dissected, weighed, minced, and placed into $20 \mathrm{ml}$ RFTM (Ray 1966) containing $5 \mu \mathrm{l} \mathrm{m}^{-1}$ Chloromycetin (Sigma Chemical Co., $2.5 \%$ in deionized water): gill, including palps (G), mantle (M), digestive gland (DG), adductor muscle (AM), and remaining tissue (REM). The REM included rectal tissue and gonadal material when present. Hemolymph was centrifuged $(1500$ to $3000 \times \mathrm{g}$, $5 \mathrm{~min}$ ), the supernate removed, and $5 \mathrm{ml}$ RFTM with $5 \mu \mathrm{m} \mathrm{ml}^{-1}$ Chloromycetin was added. Nystatin (Sigma Chemical Co., $0.1 \%$ in deionized water) was layered on top of all cultures without mixing $(2.0 \mathrm{ml}$ for tissue maximal hemolymph from adductor muscle sinuses, notched, mantle fluid drained, and oysters exsan-
guinated via the adductor muscle. After obtaining

tide-driven water from Long Island Sound but receives little freshwater input. Salinity is relatively stable, from at each collection time (Table 1 ).

Tissue analysis. Oysters (20 per site) were processed within $1 \mathrm{~d}$ of receipt at each participating facility. Shells were scrubbed to remove fouling organisms and mud, then total weights and shell dimensions (height, length, and width) were obtained. Valves were notched, mantle fluid drained, and oysters exsan-
guinated via the adductor muscle. After obtaining 
Table 1 Ambient salinity and temperature conditions measured at time of collection at each site.

\begin{tabular}{|lrcc|}
\hline Date & Florida & Virginia & New York \\
\hline Salinity (\%o) & & & \\
Oct 1993 & 27.0 & 19.5 & 25.0 \\
Dec 1993 & 32.0 & 10.5 & 26.0 \\
Mar 1994 & 6.3 & 5.0 & 25.0 \\
May 1994 & 18.4 & 8.0 & 20.0 \\
Jul 1994 & 12.0 & 17.0 & 26.0 \\
Temperature $\left({ }^{\circ} \mathrm{C}\right)$ & & & \\
Oct 1993 & 24.6 & 14.4 & 16.7 \\
Dec 1993 & 15.8 & 12.0 & 8.1 \\
Mar 1994 & 17.5 & 9.0 & 2.2 \\
May 1994 & 24.0 & 19.5 & 13.1 \\
Jul 1994 & 26.6 & 27.8 & 24.2 \\
\hline
\end{tabular}

cultures, $0.5 \mathrm{ml}$ for hemolymph cultures). All samples were incubated at room temperature $\left(-25^{\circ} \mathrm{C}\right)$ in darkness for $7 \mathrm{~d}$ to allow enlargement of Perkinsus marinus hypnospores.

After incubation samples were centrifuged (800 to $2000 \times g, 10$ to $15 \mathrm{~min}$ ) and overlying RFTM was drawn off. Sodium hydroxide (2 $\mathrm{M} \mathrm{NaOH}, 30 \mathrm{ml}$ for tissues, $5 \mathrm{ml}$ for hemolymph) was added and samples were placed in a $60^{\circ} \mathrm{C}$ oven for $2 \mathrm{~h}$ to digest remaining oyster tissue. After samples had cooled to room temperature, they were centrifuged as described above and the $\mathrm{NaOH}$ supernate was removed. Two additional washes/ centrifugation steps were performed with deionized water (DI) to remove all $\mathrm{NaOH}$. In some cases, particularly for the Long Island oysters, a viscous layer formed over the pellet during the wash steps following $\mathrm{NaOH}$ digestion. This layer of material was retained to avoid potential loss of Perkinsus marinus, and this resulted in a 'pellet' volume ranging from 0.25 to $0.75 \mathrm{ml}$. Finally, samples were resuspended in $10 \% \mathrm{NaCl}$ solution; $1 \mathrm{ml}$ for those from $\mathrm{FL}$ and VA or up to $3 \mathrm{ml}$ for NY samples. Staining, dilution and quantification methodology differed slightly among the participating laboratories and are presented separately here.

GED (FL oysters) and VIMS (VA oysters): Samples stored in $\mathrm{NaCl}$ were centrifuged as above and the $\mathrm{NaCl}$ was removed. Lugol's iodine (Fisher \& Oliver 1996 , diluted $-3: 1$ to a working concentration in deionized water) was added and the samples were mixed with a vortex to homogenize the suspension. Using a vacuum aspirator, 3 separate $100 \mu$ liquots were pipetted onto individual $47 \mathrm{~mm}$ diameter, $0.22 \mu \mathrm{m}$ pore filters (mixed cellulose ester composition), then placed on a glass slide. Counts of the blue/black-stained hypnospores were obtained under $100 \times$ magnification on a Reichert or Zeiss compound light microscope. Samples were diluted (in Lugol's working iodine) 10-fold using a volume of $100 \mu \mathrm{l}$ if counts exceeded 200, and each entire sample was concentrated and counted if counts were under 10.

HSRL (NY oysters): The viscous layer was always retained to avoid potential loss of parasites. Sample volume (stored in $10 \% \mathrm{NaCl}$ ) was recorded and stock Lugol's stain was added at the rate of approximately $350 \mu \mathrm{l} \mathrm{ml} \mathrm{m}^{-1}$. The final volume was recorded, each sample was vortex mixed and filtered as above. Samples were counted using a Zeiss compound microscope at $100 \times$. Samples were diluted if counts exceeded 300 per $100 \mu \mathrm{l}$ aliquot, and the entire sample was examined if counts were less than 10. Dilutions were made by removing 10 to $500 \mu \mathrm{l}$ of original sample and diluting to $1 \mathrm{ml}$.

For all 3 sites, whole body burdens were calculated by summing Perkinsus marinus counts for each separate tissue, then dividing by the undissected whole tissue weight plus the volume of hemolymph (ml) removed. Final parasite densities were expressed as $\log _{10}$ no. of hypnospores ( $\mathrm{g}$ wet wt tissue) $)^{-1}$ or $\log _{10}$ no. of hypnospores (ml hemolymph $)^{-1}$.

Statistical analysis. Although quantitative Perkinsus marinus diagnostic data were obtained at each participating laboratory using a common method, differences in technical personnel and equipment (e.g. centrifuges) could impose variability that would invalidate inter-site statistical comparisons. Calibration samples that consisted of finely homogenized oyster tissue were processed by all participating laboratories during the study and some results varied considerably (Fisher \& Oliver 1996). Consequently, inter-site comparisons of $P$. marinus prevalence and intensity have been limited to qualitative observations. Data from each site were subject to 2-way interactive analysis of variance (ANOVA) with date and tissue type as main effects. Where significant interaction was found, Tukey's studentized range test was conducted on all date $x$ tissue type means (including total body burdens) within a given site. If no interaction was present, 1-way ANOVAs were conducted to evaluate infection intensity differences among tissue types within date, and to test for infection intensity differences between dates for each tissue type and for total body burden. Withinsite correlational analysis (Pearson's procedure) was conducted separately for data from each site to evaluate the relative accuracy of individual tissue analyses in reflecting whole body results. All data were $\log _{10}$ transformed to satisfy an ANOVA requirement for normality of error terms. For 6 oysters from FL and 2 from NY, 1 or more individual tissue $P$. marinus counts were missing due to technical errors during oyster processing, and whole body burdens were not calculated for these oysters. Differences were considered significant at $\mathrm{p}<0.05$. 


\section{RESULTS}

\section{Florida}

Perkinsus marinus prevalence was $100 \%$ for oysters collected from FL. $\log _{10}$ total body burdens ranged from 2.15 to 5.52 , and the combined mean over all dates was 4.19. Sixty-two percent of whole-body infections ranged from 4.0 to 5.0 (Fig. 2a). There was significant interaction between date and tissue type for the FL oyster data. The highest month's average total body burden of $P$. marinus, measured in July, was significantly higher than the average for March (Table 2a, Fig. 3a), but was not significantly different from any other monthly mean body burdens. Counts from separate tissues reflected the same month-to-month trend, with the March mean always lower than that of other sample dates (Table 2a). Hemolymph data showed a slightly different pattern, with the December sample having the highest counts compared to other months (Table 2a, Fig, 3a). Hemolymph diagnoses were significantly lower than those for all other tissues and body burden in all months except December, when adductor
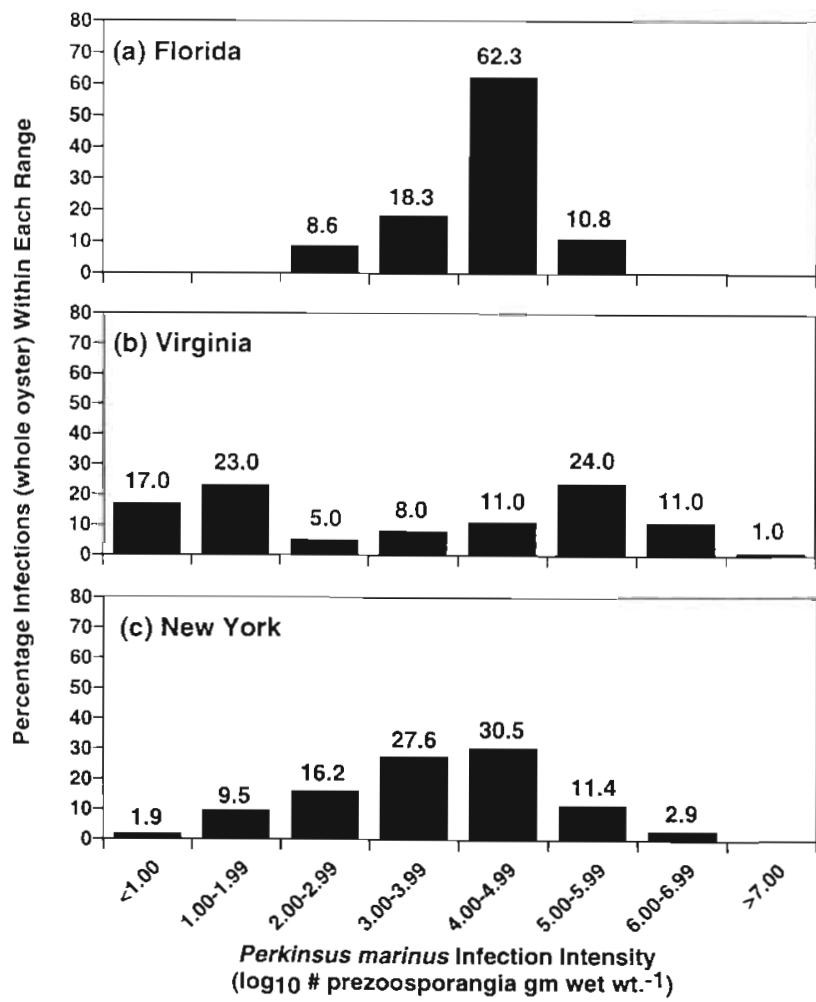

Fig. 2. Crassostrea virginica. Frequencies of whole body Perkinsus marinus infection intensities $\left(\log _{10}\right.$ no. of hypnospores g wet wt ${ }^{-1}$ ) at (a) Apalachicola Bay (Cat Point Bar), FL; (b) Chesapeake Bay (Wreck Shoal), VA; and (c) Long Island Sound (Oyster Bay), NY, over the year-long study period muscle and hemolymph results were statistically indistinguishable (Table 2a). For all months except October, the highest $P$. marinus intensity was found in the digestive gland (Table 2a). In 21 of 100 cases, no parasites were found in hemolymph samples, but body burdens ranged from 2.4 to 4.9 for FL oysters that had negative hemolymph diagnoses. For the other 5 tissues diagnosed, there were 4 instances in which an individual tissue contained no P. marinus ( 3 adductor muscle and 1 gill), although parasites were recorded for other tissues and whole body burdens ranged from 2.4 to 4.3 . Using data from all dates combined, each tissue was significantly correlated with body burden, and digestive gland showed the strongest correlation with $\mathrm{r}^{2}=$ 0.795 (Table 3). Although significantly correlated with body burden, the correlations with both hemolymph $\left(r^{2}=0.241\right)$ and adductor muscle $\left(r^{2}=0.251\right)$ were weak (Table 3).

\section{Virginia}

Perkinsus marinus prevalence was $98 \%$ for oysters collected from Wreck Shoal, VA. Two oysters sampled in May 1994 were negative. Body burdens for individuals ranged from 0 to 7.13 with a grand mean of 3.37 . Forty percent of infections were less than 2.0 , and $36 \%$ were at least 5.0 or greater (Fig. 2b). Two-way interactive ANOVA results showed significant interaction between date and tissue type. The greatest infection intensities were observed in October 1993 for all tissues and body burden (Table 2b, Fig. 3b). Mean total body burden declined between October and May, and average body burdens in March, May, and July were significantly lower than those measured in either October or December (Table 2b). The March and May mean body burdens were the lowest intensities for any site during the study. In all months, parasite densities in hemolymph were lower than in all other tissues. Counts for adductor muscle were next lowest. Digestive gland tissue had the highest counts of all tissues in December 1993, March 1994, and May 1994, whereas REM ranked highest in October 1993 and mantle tissue ranked highest in July 1994 (Table 2b). Hemolymph samples were negative for 22 oysters in which $P$. marinus was detected in other tissues, and body burdens from these oysters ranged from $<1.0$ to 4.0 . For the other 5 tissues, negative diagnoses were obtained 52 times: 10 mantle, 6 digestive gland, 11 gill, 18 adductor muscle and 7 REM. Whole body burdens for oysters that yielded some negative and some positive individual soft tissue diagnoses ranged from $<1.0$ to 4.3 , and most were below 2.0. All results from separate tissue diagnoses correlated strongly with body burden, and correlation coefficients were much higher than 
Table 2. Crassostrea virginica. Means (and standard errors) of $\log _{10}$-transformed Perkinsus marimus counts in different oyster tissues from 3 sites at 5 times of the year. (a, b) Data analyzed by interactive ANOVA with effects = date and tissue type; (c) data analyzed by 1 -way ANOVA within date with effect = tissue type. HM: hemolymph; M: mantle; DG: digestive gland; G: gill; AM: adductor muscle; REM: remainder; Total: summed body burden. Means that share a letter are not significantly different

\begin{tabular}{|c|c|c|c|c|c|}
\hline Tissue & October & December & March & May & July \\
\hline \multicolumn{6}{|c|}{$\begin{array}{l}\text { (a) Florida oysters: Interaction (date } \times \text { tissue type) significant, } p<0.0001 \text {, all date } \times \text { tissue type means tested using Tukey's } \\
\text { Studentized range test }\end{array}$} \\
\hline $\mathrm{HM}$ & $1.14(0.18) \mathrm{kl}$ & $2.84(0.15) \mathrm{ghi}$ & $0.33(0.12) 1$ & $1.55(0.16) \mathrm{jk}$ & $1.68(0.18) \mathrm{jk}$ \\
\hline M & $4.19(0.21)$ abcdef & $4.19(0.13)$ abcdef & $1.90(0.12) \mathrm{ijk}$ & $3.78(0.17)$ cdefg & $3.87(0.17) \mathrm{cdef}$ \\
\hline $\mathrm{DG}$ & $4.56(0.19)$ abcd & $4.83(0.17) \mathrm{ab}$ & $3.95(0.18)$ bcdef & $5.03(0.12) \mathrm{a}$ & $4.87(0.18) \mathrm{ab}$ \\
\hline G & $3.64(0.28)$ defg & $4.02(0.16)$ bcdef & $2.47(0.17) \mathrm{hij}$ & $3.94(0.19)$ bcdef & $4.23(0.23)$ abcde \\
\hline $\mathrm{AM}$ & $3.59(0.26) \mathrm{efg}$ & $3.75(0.14)$ cdefg & $2.44(0.13) \mathrm{hij}$ & $3.61(0.26) \mathrm{efg}$ & $3.72(0.20)$ cdefg \\
\hline REM & $4.62(0.22) \mathrm{abc}$ & $4.28(0.15)$ abcde & $2.31(0.05) \mathrm{ij}$ & $4.59(0.12) \mathrm{abcd}$ & $4.83(0.20) \mathrm{ab}$ \\
\hline Total & $4.31(0.15)$ abcde & $4.33(0.14)$ abcde & $3.27(0.16) \mathrm{fgh}$ & $4.50(0.10)$ abcde & $4.59(0.14) \mathrm{abc}$ \\
\hline \multicolumn{6}{|c|}{$\begin{array}{l}\text { (b) Virginia oysters: Interaction (date } \times \text { tissue type) significant, } p<0.0119 \text {, all date } \times \text { tissue type means tested using Tukey's } \\
\text { Studentized range test }\end{array}$} \\
\hline $\mathrm{HM}$ & $3.77(0.22)$ def & $2.84(0.29) \mathrm{fg}$ & $0.56(0.12)$ hij & $0.08(0.04) \mathrm{j}$ & $1.47(0.22)$ ghij \\
\hline M & $6.13(0.18) \mathrm{d}$ & $4.69(0.30)$ bcde & $1.10(0.25) \mathrm{hij}$ & $0.64(0.19)$ hij & $3.83(0.34)$ def \\
\hline DG & $6.15(0.15) \mathrm{a}$ & $5.27(0.21) \mathrm{abc}$ & $1.84(0.33) \mathrm{gh}$ & $1.06(0.19)$ hij & $3.32(0.46)$ ef \\
\hline G & $6.12(0.17) \mathrm{a}$ & $4.64(0.31)$ bcde & $0.99(0.22)$ hij & $0.73(0.21) \mathrm{hij}$ & $3.57(0.36) \mathrm{ef}$ \\
\hline $\mathrm{AM}$ & $5.63(0.19) \mathrm{abc}$ & $4.26(0.31)$ cde & $0.88(0.24)$ hij & $0.34(0.17) \mathrm{ij}$ & $2.79(0.40) \mathrm{fg}$ \\
\hline REM & $6.33(0.15)$ a & $5.25(0.19) a b c$ & $1.69(0.28) \mathrm{ghi}$ & $0.86(0.24) \mathrm{hij}$ & $3.30(0.40)$ ef \\
\hline Total & $6.01(0.14) a b$ & $4.98(0.18)$ abcd & $1.53(0.27)$ ghi & $0.91(0.20)$ hij & $3.41(0.37)$ ef \\
\hline \multicolumn{6}{|c|}{$\begin{array}{l}\text { (c) New York oysters: Interaction (date } \times \text { tissue type) non-significant, } p<0.7792 \text {. Analysis shown is } 1 \text {-way ANOVA with effect } \\
=\text { tissue type for each sampling date: } p \text {-values presented for each date (means within each column that share a letter are } \\
\text { not significantly different). Note: see Fig. } 3 c \text { for significant differences due to date }\end{array}$} \\
\hline & $(\mathrm{p}<0.0001)$ & $(\mathrm{p}<0.0001)$ & $(p<0.0001)$ & $(\mathrm{p}<0.0001)$ & $(p<0.0293)$ \\
\hline $\mathrm{HM}$ & $2.35(0.25) \mathrm{c}$ & $2.21(0.24) b$ & $1.73(0.26) b$ & $0.49(0.15) \mathrm{c}$ & $2.91(0.27) b$ \\
\hline M & $4.17(0.12) \mathrm{ab}$ & $3.81(0.24) \mathrm{a}$ & $3.70(0.24) \mathrm{a}$ & $1.68(0.21) \mathrm{b}$ & $4.28(0.39) \mathrm{ab}$ \\
\hline DG & $4.30(0.15) \mathrm{a}$ & $4.48(0.18)$ a & $4.25(0.21) \mathrm{a}$ & $2.91(0.28) a$ & $4.44(0.42) \mathrm{a}$ \\
\hline G & $4.14(0.18) \mathrm{ab}$ & $3.65(0.29) \mathrm{a}$ & $3.50(0.29) \mathrm{a}$ & $1.35(0.28) b c$ & $4.30(0.39) \mathrm{ab}$ \\
\hline $\mathrm{AM}$ & $3.54(0.18) b$ & $3.72(0.27) \mathrm{a}$ & $3.60(0.25) \mathrm{a}$ & $1.77(0.28) \mathrm{b}$ & $3.88(0.33) \mathrm{ab}$ \\
\hline REM & $3.88(0.13) \mathrm{ab}$ & $3.92(0.24) \mathrm{a}$ & $3.80(0.21) \mathrm{a}$ & $1.95(0.29) \mathrm{ab}$ & $4.09(0.33) \mathrm{ab}$ \\
\hline Total & $4.07(0.13) \mathrm{ab}$ & $4.01(0.21) \mathrm{a}$ & $3.85(0.21) \mathrm{a}$ & $2.29(0.26) \mathrm{ab}$ & $4.44(0.32) \mathrm{a}$ \\
\hline
\end{tabular}

those calculated for FL oysters (Table 3). The strongest correlate, $r^{2}=0.974$, was for REM.

\section{New York}

Perkinsus marinus prevalence was $100 \%$ for NY oysters throughout the project, and body burdens ranged from 0.23 to 6.41 , with an overall mean for the entire study of 3.73. Fifty-eight percent of infections were in the 3.0 to 5.0 range (Fig. $2 \mathrm{c}$ ). In contrast to data from FL and VA, there was no significant interaction between date and tissue type for the NY data. Mean total body burden was around 4.0 for all collection times except for May, when it declined significantly to 2.29 (Table 2c, Fig. 3c). The May values for individual tissues were also significantly lower than those for all other months (Fig. 3c). The density of parasites in hemolymph was consistently lower than in the other 5 tissues, and digestive gland had the highest density at all times of year (Table 2c). No parasites were found in 10 hemolymph samples from oysters with body burdens that ranged from 0.3 to 4.2 . There were negative diagnoses for 5 tissue samples: once each for mantle, digestive gland and adductor muscle, and twice for gill. Whole body burdens of these oysters ranged from 0.3 to 4.2. P. marinus intensities in all 6 tissues correlated strongly with body burden; the highest $\mathrm{r}^{2}$ was 0.910 for REM (Table 3).

\section{DISCUSSION}

The highest intensity of Perkinsus marinus in oyster tissue is typically found in late summer and fall when high temperatures favor development of heavy infec- 


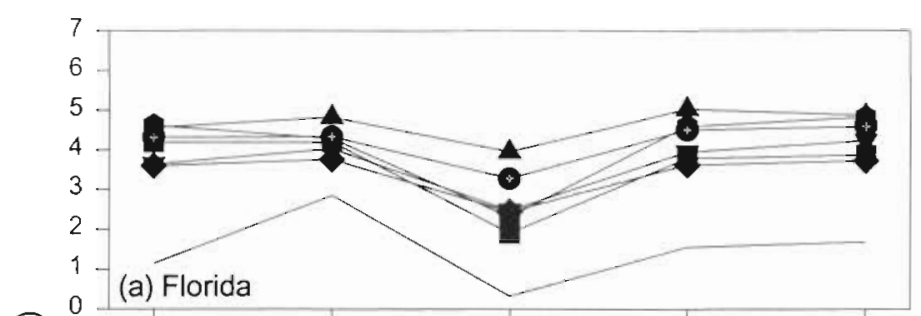

亏̇

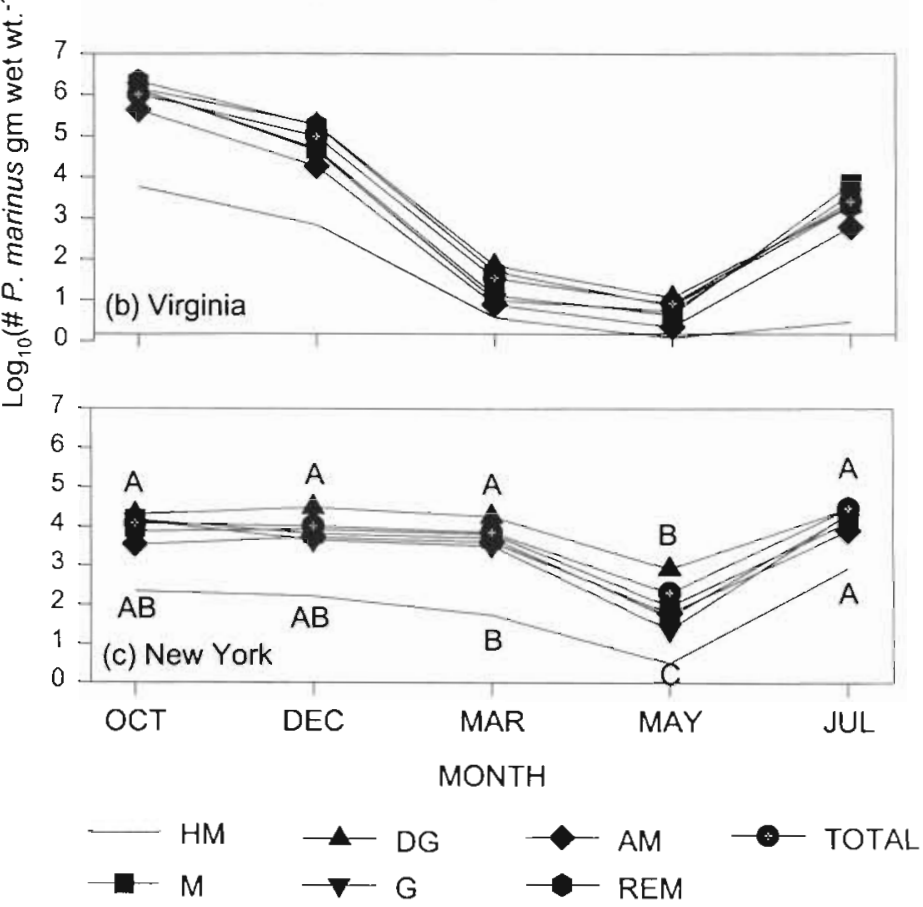

Fig. 3. Crassostrea virginica. Mean Perkinsus marinus infection intensities ( $\log _{10^{-}}$transformed) $g$ wet wt tissue $\mathrm{e}^{-1}$ or $\mathrm{ml}$ hemolymph ${ }^{-1}$ in oyster tissues from (a) Apalachicola Bay (Cat Point Bar), FL; (b) Chesapeake Bay (Wreck Shoal), VA; and (c) Long Island Sound (Oyster Bay), NY HM: hemolymph, M: mantle, DG: digestive gland, G: gill, AM: adductor muscle, REM: remainder. (c) Top set of letters indicates results of 1-way ANOVA with effect = collection date on separate tissue diagnoses and whole body burdens with subsequent Tukey's Studentized range test $(p<0.0001$ for all tissues and whole body). Lower set of letters indicates results of Tukey's Studentized range test on hemolymph counts ( $p<0.0001$ for hemolymph).

Date means that share a letter are not significantly different sites illustrate the complex involvement of biological and environmental variables that influence infection intensity and distribution in any given year

The VA oysters followed the typical seasonal pattern of infection intensity. They displayed very heavy infections $\left(\log _{10} \approx 6\right)$ in October, which decreased to light infections by May. Accompanying the decreased intensity were lowered salinities during the winter months, a condition that inhibits parasite activity (Chu \& La Peyre 1993, Ragone \& Burreson 1993). Six periodic measurements of salinity at Wreck Shoal between February and May 1994 were below $10 \%$. Reduced temperature and salinity probably reduced $P$. marinus infections, and mortalities of heavily infected oysters may have contributed to the observed decline in average infection intensity over winter.

Perkinsus marinus data from the NY site deviate from the sharp seasonal decline in infections usually associated with reduced winter temperatures. Despite the rapid and relatively steep winter decline in temperature, $100 \%$ prevalence and average whole-body intensities of approximately 4.0 persisted throughout the winter. The only significant reduction in infection intensity in NY oysters was not seen until May when temperatures were increasing (Fig. 3c). Low autumn temperatures in Oyster Bay could have restricted development of lethal infections, and the constant high salinity (about 25\% yearround; Table 1) may have allowed moderate to heavy infections to persist through the winter. As suggested by Ragone Calvo \& Burreson (1994) the synergistic effect of both low temperature and low salinity is critical in reducing $P$. marinus infection intensity. Perhaps colder temperatures reduced the destructive activity by $P$. marinus parasites and associated mortality. Lower reproductive stress, due to a shorter spawning period for NY oysters (Kennedy \& tions that often result in mortalities. This pattern has been observed in several regions within the Gulf of Mexico (Mackin 1953, Quick \& Mackin 1971, Ogle \& Flurry 1980), South Carolina (Crosby \& Roberts 1990), Chesapeake Bay (Andrews \& Hewatt 1957), Delaware Bay (Anonymous 1958 in Ford 1996), and Long Island Sound (Brousseau 1996). In southern regions, the winter minimum for infection intensity is often higher than in northern regions due to higher year-round temperatures. The major exceptions to this seasonal pattern have been associated with low salinities (Soniat 1985). In this study, contrasting patterns of infection among
Table 3. Pearson correlation coefficients $\left(\mathrm{r}^{2}\right)$ between individual tissue diagnoses and total body burdens for each site; all significant at $\mathrm{p}<0.0001$

\begin{tabular}{|lccc|}
\cline { 2 - 4 } & Florida & Virginia & New York \\
\hline Hemolymph & 0.241 & 0.771 & 0.738 \\
Mantle & 0.515 & 0.922 & 0.881 \\
Digestive gland & 0.795 & 0.930 & 0.803 \\
Gill & 0.421 & 0.922 & 0.883 \\
Adductor muscle & 0.253 & 0.902 & 0.873 \\
Remainder & 0.624 & 0.974 & 0.910 \\
\hline
\end{tabular}


Krantz 1982, Brousseau 1995), and more active cellular defense activities at cool temperatures (Fisher et al. 1989, Fisher et al. 1996) may have protected NY oysters from lethal effects. However there was no decline in average infection intensity between October and March; although the link of low temperature to decreased $P$, marinus infection is well documented (Hewatt \& Andrews 1956, Chu \& La Peyre 1993, Ragone Calvo \& Burreson 1994).

During the same time interval, a study of intertidal oysters at 3 sites on the north shore of Long Island Sound demonstrated reduced winter Perkinsus marinus infections (Brousseau 1996). At one site (Bridgeport, CT), prevalence decreased from $100 \%$ to $17 \%$ between October 1993 and February 1994. Although temperatures at Oyster Bay and Bridgeport were similar, salinity at the Bridgeport site was $15 \%$, which could have contributed to the apparently lower winter infection intensities compared with Oyster Bay. Ragone Calvo \& Burreson (1994) found that at high salinities, winter prevalence did not decline as rapidly, or to the same degree, as at lower salinities at the same temperature. Light intensity infections in Bridgeport oysters may have been missed by the mantle/rectal qualitative tissue squash method which has a detection limit of about $10^{3}$ [g wet wt tissue ${ }^{-1}$ ] (Bushek et al. 1994).

Despite higher salinities and temperatures in October and December, FL oysters had lower body burdens of Perkinsus marinus compared with VA oysters. The autumn intensity peak (and associated $P$. marinusrelated oyster mortalities) may have occurred earlier than October in FL, since the average body burden in July 1994 surpassed that measured in October 1993. Such a peak during July and August has been previously reported in Gulf of Mexico oysters (Ray 1954 . Quick \& Mackin 1971). Rapid growth of oysters in Apalachicola Bay can result in market-sized individuals in less than 15 mo (Dawson 1955), allowing oysters to 'outgrow' the parasite and reach harvestable size before $P$. marinus infections become lethal (Soniat 1996). Hofmann et al. (1995) and Powell et al. (1996) have used computer simulations to illustrate that oysters inhabiting lower latitudes may sustain a stable average infection level, although heavy infections and ensuing mortalities occur, because the rapid growth rate allows sufficient recruitment to replace dying adults. In contrast, NY oysters may require 3 yr to reach market size. Alternatively, a density-dependent reduction in parasite proliferation at high summer infection intensities may explain the relatively constant infection levels measured in both FL and NY oysters (Saunders et al. 1993)

Differences in susceptibility among oyster populations may have contributed to the contrasting patterns of infection among the 3 sites. Greater resistance to Perkinsus marinus by South Carolina oysters compared with Virginia oysters was reported by Andrews (1955). Bushek (1994) showed that oysters from populations with long exposure to $P$. marinus developed significantly lower infections than oysters with limited exposure. Oysters inhabiting the New York site have been exposed to heavy $P$. marinus parasitism only in the last few years, in contrast with the Gulf of Mexico and Chesapeake Bay where P. marinus has been present for at least 50 yr (Ray 1954, Ford 1996). In this study, although moderate-heavy infections persisted in NY oysters throughout the winter, there was no evidence of infection progression toward levels usually associated with lethality $\left(10^{5}\right.$ to $10^{7}$ parasites $[\mathrm{g}$ wet wt tissue $\mathrm{e}^{-1}$; Fisher et al. 1992). Although mortality was not measured in this study, lethality thresholds for $P$. marinus infections may differ among sites

Parasite virulence may also differ among geographically separate sites. Bushek \& Allen (1996) reported significantly heavier infections in oysters challenged with Perkinsus marinus isolates from the U.S. Atlantic coast compared with those challenged with isolates from the Gulf of Mexico. Very heavy fall infections in VA oysters, which probably caused mortalities, compared with more constant, moderate to heavy infections in FL oysters, may indicate either reduced parasite virulence or an adaptive response in Gulf of Mexico host oysters. P. marinus was recently documented in Maine (Kleinschuster \& Parent 1995), suggesting the possible emergence of a cold-tolerant strain that could explain the persistence of winter infections in NY.

For all sites studied, digestive gland densities of Perkinsus marinus tended to be the highest of all tissues (Table 2). Similar results were reported by Choi et al. (1989) and Fisher et al. (1992). Parasite density in digestive gland tissue was greater than that calculated for the whole oyster at all sites on all collection dates this must be considered if digestive gland intensity is used as an estimate of parasite density in the total oyster. REM also had relatively high parasite density, probably due to the inclusion of rectal tissue which is known to have high levels of $P$. marinus (Ray 1966). Correlations between tissue and total body levels of $P$. marinus for FL oysters were relatively poor compared with VA and NY for all individual tissues (Table 3). The reasons for this are uncertain, but may possibly relate to technical differences in oyster processing or to the distribution of $P$. marinus in FL oyster tissue

Hemolymph samples contained the lowest parasite densities of the 6 tissues. This finding, and the relatively high number of missed infections in hemolymph, was also reported by Bushek et al. (1994) who assayed $0.25 \mathrm{ml}$ hemolymph samples. In our study, an attempt 
was made to extract as much hemolymph as possible from the oysters to maximize sensitivity. The average volumes of hemolymph withdrawn at each laboratory were $1.58,1.42$, and $2.28 \mathrm{ml}$ for FL, VA, and NY, respectively; yet infections were still not found in 55 of 303 hemolymph samples. Despite higher intensity infections during certain months in FL oysters relative to VA oysters (Fig. 3a, b), there were about the same number of negative hemolymph diagnoses, suggesting possible differences in the infection process between the sites or technical discrepancies in sample processing. Correlations between total body burdens and hemolymph densities showed a weaker relationship for FL compared with VA and NY data (Table 3). Elimination of Perkinsus marinus counts from hemolymph sample volumes less than $1 \mathrm{ml}$ from the correlation analyses did not improve the model fit. Gauthier \& Fisher (1990) found a stronger relationship between body burden and hemolymph levels in oysters with relatively high intensity infections, a phenomenon reiterated by Bushek et al. (1994). Although useful for estimating $P$. marinus infections when oysters cannot be sacrificed, the hemolymph assay may underdiagnose moderate to heavy infections. When hemolymph diagnoses are used, investigators should consider that hemolymph infections are consistently lower than whole body burdens.

Results from this collaborative study impact past and future research on the oyster parasite Perkinsus marinus. Historical prevalence estimates generated from the tissue squash/rating method have probably underestimated true prevalence, as suggested by Bushek et al. (1994). Similarly, the validity of using a single tissue for surveys or monitoring work (Bushek et al. 1994) is also confirmed by our study, since each of the 6 tissues analyzed here reflected the same seasonal trend as did the summed body burdens. The choice of tissue is important depending upon the accuracy required (e.g. hemolymph diagnoses give low estimates of body burden, and digestive gland diagnoses give high estimates). The digestive gland diagnoses were the most sensitive and had the strongest correlation with total body burden. The increased accuracy gained by using the quantitative body burden assay, though more costly and time-consuming than the tissue-rating technique, is desirable for a variety of applications. Computer models suggest that accurate prediction of epizootics requires examination of infection intensity changes in sub-market size classes (Hofmann et al. 1995) which tend to have relatively light infections that could be missed by the single-tissue squash technique (Ray 1954, Soniat 1996). A quantitative, whole-oyster diagnostic method is well suited to study light-intensity, over-wintering infections (Bushek et al. 1994, Ragone Calvo \& Burreson 1994, Fisher \& Oliver 1996).
The quantitative version of Ray's (1952) technique used here allowed detection of distinct seasonal patterns of infection progression at different sites and demonstration of consistent differences in oyster tissue distribution throughout 1 year.

Acknowledgements. Weekly temperature data were provided for Cat Point Bar in FL and the York River in VA (which has a similar temperature regime as Wreck Shoal), respectively, from Lee Edmiston (FL Department of Environmenta] Protection) and the VIMS computer center; and David Relyea (Frank M. Flower \& Sons Oyster Company) provided weekly temperature data for the NY site from January to July 1994 Dr Charles Bundrick (University of West Florida) furnished invaluable advice regarding statistical analyses. This is EPA Gulf Ecology Division Contribution No. 1000. This is Contribution No. 97-20 from Rutgers Institute of Marine and Coastal Sciences and New Jersey Agriculture Experiment Station Publication No. D-32405-3-97. This is Contribution No. 2135 from Virginia Institute of Marine Science.

\section{LITERATURE CITED}

Anderson RS, Unger MA, Burreson EM (1996) Enhancement of Perkinsus marinus disease progression in TBT-exposed oysters (Crassostrea virginica). Mar Environ Res 42 $177-180$

Andrews JD (1955) Notes on fungus parasites of bivalve mollusks in Chesapeake Bay. Proc Nat Shellfish Assoc 45: $157-163$

Andrews JD (1965) Infection experiments in nature with Dermocystidium marinum in Chesapeake Bay. Chesapeake Sci 6:60-67

Andrews JD (1988) Epizootiology of the disease caused by the oyster pathogen Perkinsus marinus and its effect on the oyster industry. Am Fish Soc Spec Pub 18:47-63

Andrews JD (1996) History of Perkinsus marinus, a pathogen of oysters in Chesapeake Bay 1950-1984. J Shellfish Res 15(1):13-16

Andrews JD, Hewatt WG (1957) Oyster mortality studies in Virginı. II. The fungus disease caused by Dermocystidium marinum in oysters of the Chesapeake Bay. Ecol Monogr 27:1-25

Anonymous (1958) Summary report on the fungus disease of oysters (Dermocystidium) in Delaware Bay. New Jersey Research Laboratory. Bivalve, NJ (mimeographed)

Beckert H, Bland DG, May EB (1972) The incidence of Labyrinthomyxa marina in Alabama. Ala Mar Resour Bull 8:18-24

Brousseau DJ (1995) Gametogenesis and spawning in intertidal oysters (Crassostrea virginica) from western Long Island Sound. J Shellfish Res 14(2):483-487

Brousseau DJ (1996) Epizootiology of the parasite, Perkinsus marinus (dermo) in intertidal oyster populations in Long Island Sound. J Shellfish Res 15(3):583-587

Brousseau D, Orsine C, Rios M, Zavadoski W (1994) Preliminary results on Perkinsus marinus prevalence in oyster populations from Long Island Sound (Western). I Shellfish Res 13(1):312-313 (abstract)

Burrell VG Jr, Bobo MY, Manzi JJ (1984) A comparison of seasonal incidence and intensity of Perkinsus marinus between subtidal and intertidal oyster populations in South Carolina. J World Maricult Soc 15:301-309 
Burreson EM, Alvarez RS. Martinez VV. Macedo LA (1994) Perkinsus marinus (Apicomplexa) as a potentual source of oyster Crassostrea virginica mortality in coastal lagoons of Tabasco, Mexico. Dis Aquat Org 20(1):77-82

Burreson EM, Ragone Calvo LM (1996) Epizootiology of Perkinsus marinus disease of oysters in Chesapeake Bay, with emphasis on data since 1985. J Shellfish Res 15(1): $17-34$

Bushek D (1994) Dermo disease in American oysters: genetics of host-parasite interactions. PhD dissertation, Rutgers The State University, New Brunswick, NJ

Bushek D, Allen SK Jr (1996) Host-parasite interactions among broadly distributed populations of the eastern oyster Crassostrea virginica and the protozoan Perkinsus marinus. Mar Ecol Prog Ser 139:127-141

Bushek D, Ford SE, Allen SK Jr (1994) Evaluation of methods using Ray's Fluid Thioglycollate Medium for diagnosis of Perkinsus marinus infection in the Eastern oyster, Crassostred virginica. Ann Rev Fish Dis 4:201-217

Choi KS, Wilson EA, Lewis DH, Powell EN, Ray SM (1989) The energetic cost of Perkinsus marinus parasitism in oysters: quantification of the thioglycollate method. I Shellfish Res 8(1): 125-131

Chu FLE, Hale RC (1994) Relationship between pollution and susceptibility to infectious disease in the eastern oyster. Crassostrea virginica. Mar Environ Res 38:243-256

Chu FLE, La Peyre JF (1993) Perkinsus marinus susceptibility and defense-related activities in eastern oysters Crassostrea virginica: temperature effects. Dis Aquat Org 16 $223-234$

Chu FLE, La Peyre JF, Burreson CS (1993) Perkinsus marinus infection and potential defense-related activities in eastern oysters, Crassostrea virginica, salinity effects. J Invertebr Pathol 62:226-232

Craig A, Powell EN, Fay RR, Brooks JM (1989) Distribution of Perkinsus marinus in Gulf coast oyster populations. Estuaries 12:82-91

Crosby MP, Roberts CF (1990) Seasonal infection intensity cycle of the parasite Perkinsus marinus (and an absence of Haplosporidium spp.) in oysters from a South Carolina salt marsh. Dis Aquat Org 9:149-155

Dawson CE (1955) Observations on the incidence of Dermocystidium marinum infection in oysters of Apalachicola Bay. Tex J Sci $7(1): 47-56$

Fisher WS, Chintala MM, Moline MA (1989) Annual variation of estuarine and oceanic oyster Crassostrea virginica Gmelin hemocyte capacity. J Exp Mar Biol Ecol 127 $105-120$

Fisher WS, Gauthier JD, Winstead. JT (1992) Infection intensity of Perkinsus marinus disease in Crassostrea virginica (Gmelin, 1791) from the Gulf of Mexico maintained under different laboratory conditions. J Shellfish Res 11(2): $363-369$

Fisher WS, Oliver LM (1996) A whole-oyster procedure for diagnosis of Perkinsus maninus disease using Ray's fluid thioglycollate culture medium. J Shellfish Res 15(1): 109-117

Fisher WS, Oliver LM, Edwards PE (1996) Hematologic and serologic variability of eastern oysters from Apalachicola Bay, Florida. J Shellfish Res 15(3):555-564

Fisher WS, Oliver LM., Sutton EB, Manning CS, Walker WW (1995) Exposure of eastern oysters to tributyltin increases the severity of Perkinsus marinus disease. J Shellfish Res 14(1):274 (Abstract)

Ford SE (1996) Range extension by the oyster parasite Perkinsus marinus into the northeastern United States: response to climate change? J Shellfish Res 15(1):45-56
Gauthier JD, Fisher WS (1990) Hemolymph assay for diagnosis of Perkinsus marinus in oysters Crassostrea virginica (Gmelin, 1791). J Shellfish Res 9(2):367-371

Hewatt WG, Andrews JD (1956) Temperature control experiments on the fungus disease, Dermocystidium marinum of oysters. Proc Natl Shellfish Assoc 46:129-133

Hofmann EE, Powell EN, Klinck JM, Saunders G (1995) Modeling Perkinsus marinus infections in oysters. $J$ Shellfish Res 14(1): 121-151

Kennedy VS, Krantz LB (1982) Comparative gametogenic and spawning patterns of the oyster Crassostrea virginica (Gmelin) in central Chesapeake Bay. J Shellfish Res 2(2): $133-140$

Kleinschuster SJ, Parent J (1995) Sub-clinical infection of oysters (Crassostrea virginica) (Gmelin 1791) from Maine by species of the genus Perkinsus (Apicomplexa). J Shellfish Res 14(2):489-491

Lewis DH, Choi KS, Powell EN (1988) Technique for purifying Perkinsus marinus hypnospores. J Shellfish Res 7(1):204 (Abstract)

Mackin JG (1951) Histopathology of infection of Crassostrea virginica (Gmclin) by Dermocy'stidium marinum Mackin, Owen and Collier. Bull Mar Sci Gulf Caribb 1:72-87

Mackin JG (1953) Incidence of infection of oysters by Dermocystidium in the Barataria Bay area of Louisiana. Proc Natl Shelifish Assoc 42:22-35 (Convention addresses, 1951)

Mackin JG, Owen HM, Collier A (1950) Preliminary note on the occurrence of a new protistan parasite, Dermocystidium marinum n.sp. in Crassostrea virginica [Gmelin]. Science 111:328-329

Ogle J, Flurry K (1980) Occurrence and seasonality of Perkinsus marinus (Protozoa: Apicomplexa) in Mississippi oysters. Gulf Res Rep 6(4):423-425

Perkins FP (1966) Life history studies of Dermocystidium marinum, an oyster pathogen. PhD dissertation. Florida State University, Tallahassee. Dissertation Abstracts, 66-9078

Powell EN, Klinck JM, Hofmann EE (1996) Modeling diseased oyster populations. II. Triggering mechanisms for Perkinsus marinus epizootics. J Shellfish Res 15(1): $141-165$

Quick JA Jr, Mackin JG (1971) Oyster parasitism by Labyrinthomyxa marina in Florida. Fla Dep Nat Resour Mar Res Lab Prof Pap Ser 13:1-55

Ragone LM. Burreson EM (1993) Effect of salinity on infection progression and pathogenicity of Perkinsus marinus in the eastern oyster, Crassostrea virginica (Gmelin). J Shellfish. Res 12(1):1-7

Ragone Calvo LM. Burreson EM (1994) Characterization of overwintering infections of Perkinsus marinus (Apicomplexa) in Chesapeake Bay oysters. J Shellfish Res 13(1): $123-130$

Ray SM (1952) A culture technique for the diagnosis of infection with Dermocystidium marinum in oysters. Proc Natl Shellfish Assoc 42:9-13

Ray SM (1954) Studies on the occurrence of Dermocystidium marinum in young oysters. Proc Natl Shellfish Assoc 44: 80-92 (Convention addresses, 1953)

Ray SM (1966) A review of the culture method for detecting Dermocystidium marinum, with suggested modifications and precautions. Proc Natl Shellfish Assoc 54:55-69

Saunders GL, Powyell EN, Lewis DH (1993) A determination of in vivo growth rates for Perkinsus marinus, a parasite of the eastern oyster Crassostrea virginica (Gmelin, 1791). J Shellfish Res 12(2):229-240

Scott GI, Middaugh DP, Sammons TI (1985) Interactions of chlorine-produced oxidants (CPO) and salinity in affecting lethal and sublethal effects in the eastern or Amencan 
oyster, Crassostrea virginica (Gmelin), infected with the protistan parasite, Perkinsus marinus. In: Vernberg FF, Thurberg FP, Calabrese A, Vernberg WB (eds) Marine pollution and physiology: recent advances 1985. Unversity of South Carolina Press, Columbia, SC, p 351-376

Soniat TM (1985) Changes in levels of infection of oysters by Perkinsus marinus, with special reference to the interaction of temperature and salinity on parasitism. Northeast

Editorial responsibility: Albert Sparks,

Seattle, Washington, USA
Gulf Sci 7(2):171-174

Soniat TM (1996) Epizootiology of Perkinsus marinus disease of eastern oysters in the Gulf of Mexico. J Shellfish Res 15(1):35-43

Winstead JT, Couch JA (1988) Enhancement of protozoan pathogen Perkinsus marinus in American oysters Crassostrea virginica exposed to the chemical carcinogen $\mathrm{n}$ nitroso diethylamine (DENA). Dis Aquat Org 5:205-213

Submitted: March 11, 1997; Accepted: May 18, 1998

Proofs received from author(s): September 4, 1998 